\title{
Encontro de duas culturas: América e Europa
}

\section{FRANCISCO IGLÉSLAS}

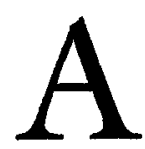

palavra descobrimento, empregada com relação a continentes e países, é um equívoco e deve ser evitada. Só se descobre uma terra sem habitantes; se ela é ocupada por homens, não importa em que estágio cultural se encontrem, já existe e náo é descoberta. Apenas se estabclece seu contato com outro povo. A expressão descobrimento implica em uma idéia imperialista, de encontro de algo nấo conhecido; visto por outro que proclama sua existência, incorporando-o ao seu domínio, passa a ser sua dependente.

Tornou-se comum o uso da expressão para os movimentos realizados no fim da Idade Média e começos da Idade Moderna, quando se verifica o maior expansionismo assinalado na história. Falou-se fartamente de descobrimentos realizados pelos portugueses e espanhóis na costa ocidental da África e em ilhas do Oceano Atlântico. E multiplicam-se as datas de revelaçáo de realidades geográficas ou humanas, desde a ilha de Porto Santo, em 1418, a dezenas de outras, bem como acidentes do litoral do continente africano. Alguns acontecimentos tiveram enorme ressonância, como a passagem do extremo sul, chamada Cabo das Tormentas ou Cabo da Boa Esperança, em 1488, por Bartolomeu Dias, desfazendo-se uma das lendas da geografia medieval. Ou a de Cristóvão Colombo, genovês a serviço da Espanha, em 1492, com a revelação do Novo Mundo ou da América. A do português Vasco da Gama, que chegaria à Índia em 1498, agora pela via marítima. Entre 1519 e 1522 é feita a primeira viagem de circunavegação, iniciada pelo português Fernão de Magalhães e concluída por Sebastian del Cano.

Ora, antes de tais empresas, em plena Idade Média, houve as viagens de italianos - notadamente genoveses, além do Mediterrâneo, incursionando pelo oceano. Delas dá notícias Jacob Burckhardt em $A$ cultura do Renascimento na Itália, de 1860 , na quarta parte - "Descobrimento do mundo e do homem", destacando viagens ainda no século XIII: o historiador vê aí características de abandono de traços medievais no que supóe o homem novo do Renascimento (1). Houve também as de nórdicos, chegando a várias partes do Atlântico norte, mesmo às ter- 
ras depois conhecidas como americanas. Se de muitas dessas entradas tem-se apenas vaga notícia, das quais se pode duvidar, houve certamente o ciclo do devassamento do desconhecido pelos italianos e mais ainda nórdicos. Já na Antiguidade houve iniciativas audaciosas, por terras e por mares, às vezes até de grande alcance, como as realizadas por fenícios, gregos, cartaginescs $\mathrm{c}$ romanos, fundando colônias em pontos distantes. Não se falava entāo em descobrimento, mas em aventuras de viajantes, em busca de riquezas, possíveis redes de comércio.

Decerto, o surto expansionista mais vigoroso e expressivo é o dos séculos XV e XVI. Basta olhar para o esquema da convencionada história geral ou universal, que não é geral nem universal, mas apenas a história da Europa, ou, melhor ainda, dos povos em torno do Mar Mediterrâneo: norte da África, Oriente Próximo e sul da Europa, com referências às vezes pormenorizadas às outras partes do mesmo continente, ou, vagas e inseguras, às outras partes.

Com as viagens incentivadas e feitas sobretudo pelos portugueses, desde o início do sćculo $\mathrm{XV}$, tem vigor o expansionismo, que requer organização e principalmente audácia para vencer os enganos da geografia antiga ou os preconceitos populares de águas ferventes, povoadas por monstros fantásticos, destruidores de embarcaçóes, pela ousadia de enfrentar o desconhecido. Os feitos de fenícios, italianos ou nórdicos seriam repetidos e até ultrapassados pelos portugueses; eles se organizaram para sua execução, formando uma verdadeira escola de marinhagem. Portugal estava fatalizado para esse trabalho, por sua posição no extremo da Europa: a vizinhança de Castela impedia-lhe crescer no continente, era preciso avançar pelos mares. $O$ precário comércio entre o sul e o norte, as cidades italianas e as da Liga Hanseática, quando feitas pelo mar, tinham de passar pela costa portuguesa, no uso de seus portos para reabastecimento ou descanso, origem de segmentos voltados para o comércio.

Dois poetas portugueses cantaram esses feitos em suas obras: Luís de Camóes, em 1572, na epopéia Os lusíadas, e Fernando Pessoa, já em nossos dias, no livro Mensagem, de 1935. Eles são também relembrados e reconstituídos pelos cronistas de então. Sabe-se serem portugueses alguns dos maiores cronistas, em um aspecto importante da historiografia no fim da Idade Média e nos séculos XV e XVI. Se Portugal tem hoje uma rica historiografia, teve-a desde essa época recuada, com alguns nomes fixadores de sua trajetória como povo e nação, enquanto lhe deram vigor à língua e à literatura.

A propósito da historiografia dos cronistas, recorde-se a de língua 
espanhola dos séculos XVI e XVII, esta, além de seu alto significado para os cstudos históricos, teve também um papel original na vida literária, devidamente destacado pelo romancista peruano Mario Vargas Llosa em belo artigo recente, no qual realça "as crônicas e relatos do descobrimento e da conquista, livros que, além de constituírem um precioso testemunho sobre aquele sangrento encontro de europeus e americanos, fundaram um novo gênero: aquele que, $\mathbf{5 0 0}$ anos mais tarde, os críticos do Velho Mundo chamaram de 'realismo mágico' " (2). Original ou nāo, é admirível atribuir a esses cronistas, notadamente os da Conquista, europeus ou americanos, a prioridade no "realismo mágico" do qual são expoentes hoje alguns ficcionistas latino-americanos, em nota de vanguarda na literatura do final do século XX (Emancipadas, cx-colónias não cooperam com indios, "Folha de S. Paulo", Caderno Especial de 12 de outubro de 1991).

O expansionismo, ou a superação da era do Mediterrâneo pela do Atlântico c do Índico, é um momento decisivo na história, quando se alargam os horizontes econômicos e políticos como os geográficos. Supera-se aos poucos o limite do homem medieval, não só $\mathrm{cm}$ extensōes mais dilatadas, incluindo a Ásia, a África e a América, como também com uma nova visão do humano e do social, não mais preso ao teocentrismo da Idade Média, mas aberto ao antropocentrismo que vai caracterizar a Idade Modema. Valoriza-se o culto da Natureza, a pesquisa, o experimentalismo, aos poucos sobrepostos aos velhos dogmas. Não se diga estar aí o começo da ciência, pois o estudioso de história deve estar sempre prevenido contra a fixação de marcos de origem e de fim, bem advertido por Marc Bloch, na denúncia da "hantise des origines", em sua bela Apologie pour $L$ histoire (3). Não terá sido o começo- de impossível fixaçāo - , mas foi um momento importante na trajetória do pensamento científico, na imposição dos valores do Racionalismo, como se consagrará nos séculos seguintes.

O alargamento do horizonte geográfico e humano, com novas terras e novos povos, é completado com as criações científicas e artísticas do Renascimento (relembre-se Burckhardt), com a quebra da unidade monolítica do cristianismo, operada pela Reforma, a consolidação dos estados nacionais. Se toda época defronta o novo e tem algo a acrescentar, algumas são particularmente inovadoras, mais que outras, como assinalou Ortega y Gasset, falando em épocas cumulativas e épocas eliminatórias e polêmicas, ou revolucionárias (4). O século XVI foi revolucionário, não cumulativo; é pobre ou sem sentido apontá-lo como uma época de transição, pois todas são épocas de transição para quem tem sensibilidade histórica, sabe perceber o novo, a permanente mudança, 
embora às vezes de difícil apreensão, pois a mudança, no eterno fluxo, tāo bem aprecndido pelos filósofos pré-socráticos, é a única realidade de fato constante.

Destaque-se, no surto expansionista, o aspecto geográfico, com a revelaçấo de novas terras; no caso de 1492, não de uma ilha ou simples parte, mas de um continente até então desconhecido. Este resulta da viagem de Cristóvão Colombo naquele ano. $O$ feito é digno de nota, decorreu dc uma idéia fixa que o obsecava, ou seja, chegar ao Oriente pelo Ocidente, fantasiosa para a maioria de seus contemporâneos. Perseguiu-a longamente, obteve o apoio de Castela e Aragão e pretendeu haver chegado à Índia, meta desejada como riqueza conhecida por alguns, cujos textos ou mapas foram lidos e estudados pelo navegante. Em 1492 os Reis Católicos passam a disputar com o português na ânsia de incorporação de outras terras. Portugal fazia-o há muito, por sua geografia, pelo pioncirismo nos mares e sua precoce unidade política, ainda na Idade Média, no século XII. $O$ vizinho ibero realiza na última década a definitiva expulsão dos árabes, aí instalados desde 711, quase no começo do período medieval, bem como a dos judeus. Em momento decisivo de sua trajetória, pode entregar-se à aventura dos mares e a realiza com extraordinários feitos.

Não importa discutir se o empreendimento teve predecessores, como é do gosto de estudiosos preocupados em estabelecer prioridades, roteiros, datas e nomes, comprazendo-se em minúcias destituídas de maior significado. Teve-os, por certo, como se vê por abundante informaçāo. Essas empresas, porém, não se impuseram ou não iniciaram um ciclo, enquanto a sua teve esse papel pioneiro. Aquelas não tiveram a eficácia histórica de que falava Ortega y Gasset e, assim, não contam, pois nâo foram e jamais serăo sabidas.

O presente Simpósio não é para discutir essa viagem ou a figura do navegante, mas para realçar, como diz o título cujo exame nos foi dado fazer, o choque de duas culturas. Do encontro de duas culturas só poderia resultar um choque, pois se tratava de culturas muito diversas: a européia, já milenar e consolidada, com um continente de enormes dimensóes e povoado, na maior parte, por povos de cultura bem menos elaborada. Colombo ignorou o que era esse mundo ao qual chegara: fascinado pela idéia da Índia, estava convencido de que aí se encontrava. O nome de índio, dado aos seus habitantes, é símbolo do equívoco. Embora tenha vindo mais três vezes na longa travessia, em uma delas tocando em terras do continente - chegara às ilhas, percorrera diversas, morrendo, contudo, 14 anos depois da primeira viagem, sem saber que 
não estivera nas terras referidas por Marco Polo, entre outros cuja informação conhecia, mas em um novo mundo.

O Simpósio não é para glorificar ninguém, mas para a análise crítica do significado desse encontro de duas culturas. A propósito, quero que fique bem claro não participar do triunfalismo comum nas histórias comemorativas, promovidas em geral pelos governos, só lembrados da história em datas especiais, em eventos já suspeitos até na escolha dessas datas, quando procuram fundar na história as supostas razóes de seu poder ou domínio, seja de nações, seja de classes. São sobretudo destituídas de sentido crítico, feitas muitas vezes por gente sem o seu entendimento, apenas por dever ou conveniência. Tal não é o caso dos promotores deste encontro, distantes da história comemorativa, pois têm a noção de que o ano de 1492 , se lembra a viagem vista em geral como a revelação da América, lembra também o terrível genocídio de milhões de nativos, espoliados de suas terras pelo conquistador europeu, às vezes com a justificativa da catequese para o cristianismo ou para civilizar povos vistos como em estádio inferior, carentes de assistência ou de tutela, em pervertida concepção.

O expansionismo geográfico foi uma face da nascente situação capitalista, em sua forma agressiva do imperialismo. Ele se verificou por uma fatalidade da economia de mercados em crescimento, com a classe burguesa em seu élan inicial, atenta apenas ao lucro, com a urbanização, a agonia da estrutura feudal e o impulso dominador da colonização. Ora, todo colonialismo é selvagem, desumano. É tolo problema questionar se o colonialismo espanhol foi melhor ou pior que o português, o francês, o holandês, o inglês. $O$ mal estava no colonialismo em si, como está em qualquer dominação. Impóe-se o estudo do momento, não para glorificar um povo ou certo herói - a história os dispensa -, mas para entender a dinâmica do processo evolutivo.

É pueril supor que o chamado Novo Mundo continuaria desconhecido. Se não fosse o espanhol, seria o português ou outro qualquer e a situação a mesma, pois o dominador só vê suas vantagens. A celebração da data náo é feita para exaltar a viagem ou a conquista, mas para estudá-la, criticamente. Nâo vem ao caso apontá-la à execração, como penitência pelo genocídio de milhóes de homens e de culturas. Como declarou em lúcida entrevista o antropólogo Lévi-Strauss - um dos maiores conhecedores da questão indígena na América; ele teve no seu estudo uma das bases da elaboraçáo do estruturalismo - " eu não quero dizer que os quinhentos anos não tenham sentido. $O$ que eu não gostaria é que se tirasse deste aniversário uma espécie de glória" (5) (entrevista a An- 
toine de Gaudemar, do Libération, de Paris, transcrita em Folba de $S$. Paulo, de 5 de outubro de 1991).

O Simpósio nāo é para glorificar ninguém, afirmou-se, mas para a análise crítica do encontro de duas culturas. Decerto seria não o de duas, mas de várias culturas. Não se pode ver como unidade a cultura européia, se ela apresentava, ontem como hoje, enormes diversidades. Havia muitas culturas européias. Fixem-se apenas as da Península Ibérica - elas estabeleceram o diálogo, as outras vieram depois: há matizes entre as vírias partes do universo espanhol, como há diferenças entre os espanhol e o português. Mesmo este, menor em área e habitantes, também conhece múltiplas manifestaçóes.

Se do lado curopeu não havia unidade, o mesmo se pode dizer do lado americano. Extensas partes eram completamente despovoadas ou de rarefeita população, em outras havia apreciáveis núcleos humanos. $O$ nível dessas concentraçóes era muito diversificado. No México se encontra a cultura asteca, mais para o sul, a cultura maia, mais para o sul, ainda, a cultura inca, todas de grande desenvolvimento técnico, alto nível científico e artístico, como se vê nas ruínas ainda presentes de seu passado destruído pela conquista, ou na complexa organizaçáo estatal. Nas áreas restantes, bem mais amplas, encontram-se culturas menos elaboradas. Tal é o caso, por exemplo, do Brasil, em cujo território existiam grupos que náo haviam superado a chamada Idade da Pedra.

O conquistador não vinha para catequizar, converter ao cristianismo, mas para obter riquezas. O eldorado seria o depósito, sobretudo de ouro e prata, de pedras preciosas. À falta desses, como se deu com os primeiros visitantcs - caso de Colombo e seus companheiros - apelava-se para submeter seus povos, reduzindo-os à escravidáo. Em contato com astecas, maias $\mathbf{e}$ incas, foi possível ao espanhol realizar saques vultosos, que intundaram de ouro e prata a Europa ocidental, provocando ali a revoluçáo dos preços, objeto de muito estudo valioso. $\mathrm{O}$ relacionamento entre essa revolução dos preços e os metais preciosos vindos da América foi feito em pleno século XVI, na obra de Jean Bodin - Réponse aux paradoxes de $M$. de Malestroit touchant l'enrichissement de toutes les choses et des monnaies, de 1568: enquanto Malestroit náo entendia a situação, apresentando paradoxos - a alta dos preços não obedecia a catusas reais, mas nominais, como a variaçáo do valor da moeda -, o agudo Jean Bodin percebia o impacto dos metais preciosos, jogados subitamente no mercado, provocando inflação incontrolável, em prova de que a altà era real, pois não só se dava mais moeda nominal mas também mais metais - ouro e prata, em excesso, levavam à depreciação do meio circulante. Mais uma vez se demonstrava a teoria quantitativa da moeda. 
Portugal, por sua vez, desequilibraria o mercado europeu, com os produtos orientais, vindos de fato da Índia, cujo domínio em parte realiza, com as especiarias, pedras e metais, tecidos finos; no terceiro século da conquista, com o achado do ouro e do diamante nas terras do Interior, expressivamente chamadas de Minas Gerais, vai provocar outra onda de provisionamento de ouro e pedras. Os iberos - espanhóis e portugueses - revelaram falta de visão econômica da gerência dos bens importados da Amćrica, o que justificara há muito o texto mercantilista do italiano Antônio Serra - Breve trattato delle cause che possono fare abbondare i regni d'oro e d'argento, dove non sono miniere con aplicaziond al Regno di Napoli, de 1613, cujo título já é suficientemente explícito, como é comum na literatura de então.

A conquista foi facilitada pelas dissensóes internas entre os grupos

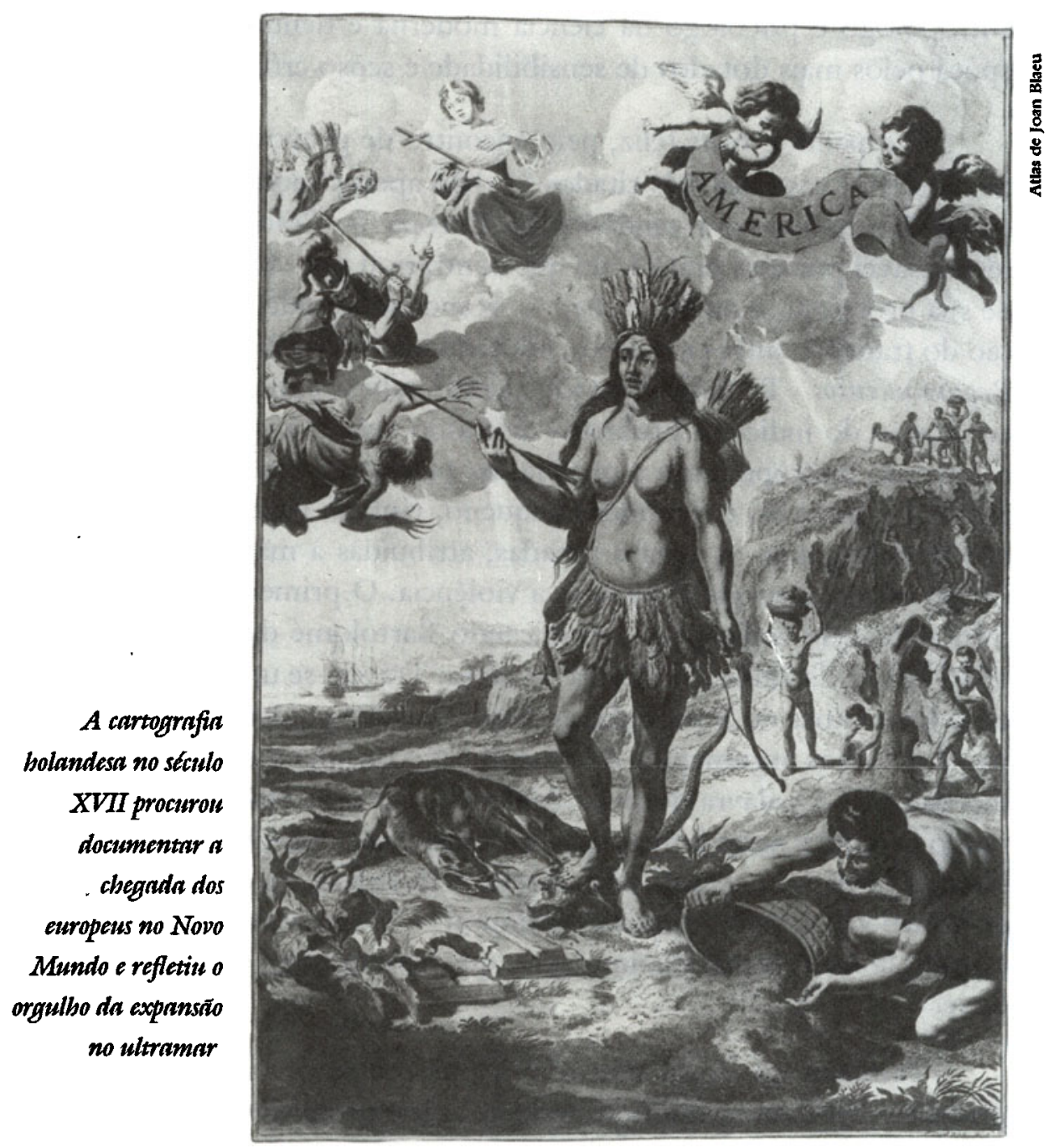


nativos: assim entre os astecas, assim entre as rudes tribos brasileiras, em permanente estado de guerra umas com as outras. A falta de união entre elas possibilitou alianças vantajosas de iberos com os nativos - ou de franceses com os nativos, no caso do Brasil, por breves períodos. Demais, a presença do padre, do missionário católico em sua pregação, introduziu práticas religiosas imitadas pelos nativos, mesmo sem o entendimento de quanto viam ou ouviam, em mero mimetismo. Além do patrimônio dos primitivos habitantes, saqueados pelo espanhol, o índio se viu atingido $\mathrm{em}$ suas crenças, verificando-se um processo de desagregação intelectual. Não se submete sem muita luta, e milhōes de criaturas morreram ante armas de fogo, de maior eficácia que as suas. Morrem de doenças trazidas pelo invasor, por maus tratos, trabalhos excessivos. Sem falar no choque em seus padróes culturais, cujo ataque em nome de uma suposta catequese religiosa acabou por destruí-los, com a desestruturação de suas personalidades, em processo perverso já muito estudado por antropólogo e psicólogo da ciência moderna e denunciado na própria época pelos mais dotados de sensibilidade e senso crítico.

O espanhol, mais feliz, pelo encontro de grupos de boa organização social - caso dos três citados - , não apenas saqueou e submeteu à escravidáo índios para vendê-los na Europa - Colombo foi bastante responsável por essa prática, no que contrariou por vezes determinaçóes de sua protetora, a rainha Isabel -, como, sobretudo, usou a organização do trabalho entre os nativos, adotando as encomiendas, as mitas, os Repartimientos. Trabalho forçado, lembrando a antiga servidáo. A escravização do índio foi problema discutido desde os primeiros anos. Se o governo metropolitano a proibia, na prática ela era feita pelo colonizador. Os brancos, em número pequeno, vinham para obter vantagens, não se entregando às tarefas pesadas, atribuídas à massa da populaçăo. Como esta se insurgisse, usou-se a violência. $O$ primeiro eco da disputa foi a defesa do índio pelo dominicando Bartolomé de las Casas, já em 1515 indo à Espanha, em defesa da causa. Travou-se uma polêmica entre ele e Juan Ginés de Sepulveda, defensor da subjugação do nativo, com o uso dos velhos argumentos de Aristóteles, considerando válido o trabalho escravo. A palavra do papa Paulo III, em uma bula de 1537, declarando os índios seres humanos, com uma alma e passíveis de se converterem à fé cristá, portanto com direito à liberdade e a seus patrimônios, de pouco valeu, pois a prática continuou - em muitas partes da colônia espanhola com formas dissimuladas, que lembravam a servidão, como se disse.

Também no Brasil houve a disputa entre os colonizadores e os primeiros habitantes, multiplicando-se as leis proibitivas do uso da força 
de trabalho indígena, em prova de não serem cumpridas. $O$ governo tinha de reiterar a proibiçáo pela sua náo-observância pelos senhores. A defesa do nativo coube a algumas ordens religiosas, notadamente a dos jesuítas, sem conseguirem evitar o uso e o abuso. No Sul do País houve formas dissimuladas, nas aldeias ou redufóes, em interessante experiência. Ante o seu malogro, apelou-se para a vinda do negro africano, a mão-de-obra básica, mais viva no Brasil, nas colônias inglesas da América do Norte e nas Antilhas que na América espanhola (esta não a desconheceu, é claro).

A real defesa do índio não foi a Igreja nem o governo, mas a sua natural rebeldia, causada sobretudo pela inadequaçáo de sua cultura livre e nômade, não tolerava o trabalho sedentário e reagia; tal como na parte espanhola, a maioria morreu, vítima não só da violência do explorador como de doenças transmitidas pelo branco - eles trouxeram algumas, ante as quais o organismo do índio não tinha reaçáo; contaminado, sucumbia, em devastadores surtos epidêmicos. Se o invasor trouxe o sarampo, a gripe, a varíola e outros males, o índio passou-lhe (ou terá aumentado?) a sífilis, transmitida pelo intenso intercurso sexual. Além da guerra de flechas e armas de fogo, houve a guerra bacteriológica, na qual também os europeus terão levado vantagem. Demais, houve os castigos e o tratamento brutal, responsáveis pela onda de suicídios entre os primitivos e legítimos habitantes da terra espoliada. A destruiçáo de seus valores culturais o desestrutura, como se dá com as personalidades. $O$ índio, antes dono, vê-se expulso ou subjugado, tal como se verifica também com o negro. Deslocado de seu meio, sofre a exploração perversa e esta lhe tira o sentido da vida.

Se os iberos muito determinaram, com imposiçóes que não recuavam ante a violência mais crua, também aprenderam bastante com os nativos. Se deram práticas, produtos, técnicas, usos e crenças, também aprenderam práticas, produtos, técnicas, usos e até crenças. Ante a força e a superioridade do equipamento do invasor, o resultado foi náo só a submissão, mas, pior ainda, o arrasamento em massa. Houve na América - repita-se - um dos maiores genocídios verificados na história, com a mortandade talvez da maioria. Destruíram-se culturas florescentes, como a asteca. Ela ilustra o que Arnold J. Toynbee, em sua tipologia das culturas, em $A$ study of history, publicado entre 1934 e 1961 (doze volumes), com justeza chamou de culturas decepadas ou abortadas. Estas náo foram, como outras por ele objeto de estudo, culturas que viveram um ciclo integral, passando dos começos para o esplendor e daí para a decadência. Elas não esgotaram seu potencial, como se vê na análise de Toynbee ou na de Spengler, de certo modo repisando as teorias do ciclo, 
já apresentadas por Vico, mas se vêem massacradas quando se encontram em cvolução, longe ainda do esgotamento de suas virtualidades.

Sabe-se da repercussĩo na Europa de livros de quantos estiveram na América. As ediçōes se sucediam, havia interesse, mas em termos de exotismo. Idealizava-se o Novo Mundo, tinha-se dele uma imagem distorcida, terra infermal ou paradisíaca. A força das lendas sobre riquezas e maravilhas foi uma das molas das viagens e da colonização, como estudou com profundidade Sérgio Buarque de Holanda, na tentativa de fixar os "motivos edênicos no descobrimento e colonização do Brasil", como se lê no subtítulo de seu notável livro Visẫo do paraíso (1958).

Segundo ele, mais que no Brasil, foi sensível o peso de tal motivação no mundo espanhol. Como escreveu, "o gosto da maravilha e do mistério, quase inseparável da literatura de viagens na era dos grandes descobrimentos marítimos, ocupa espaço singularmente reduzido nos escritos quinhentistas dos portugueses sobre o Novo Mundo". Mais adiante: "é significativa e minguada a quase nenhuma participação da fantasia que os anima nos feitos que marcam estabelecimentos dos portugueses em terras do Brasil. Nada há, certamente, em nossa história colonial, que possa medir força com aqueles gigantes, aquelas amazonas, aqueles pavorosos cinocéfalos, ou que se equipare aos países de sonho, presentes todos, já na história de Amadis, e que, no entanto, se vão realizando perante os conquistadores castelhanos das Índias" . Para Sérgio, os portugueses " não deram nenhum elemento, ainda que hesitante e vago, àquela apologia do homem primitivo, que se náo surge, a bem dizer, na era dos grandes descobrimentos marítimos animando uma das manifestações mais duradouras e fecundas do mito paradisíaco, há de desenvolver-se certamente com estes, para desabrochar futuramente nas teorias da 'bondade natural' e no mundo do nobre e bom selvagem". Como evidencia o autor, no Brasil contou a idéia de maravilha com o ouro e a pedra preciosa: "o importante é que nâo pareceram ausentes, mas foram, ao invés disso, dos fatores ativos da expansão colonizadora, as mesmas manifestaçóes sobrenaturais que em toda parte em que e em quase todos os tempos formaram o cortejo mágico e o resplendor das minas preciosas" (6). Apesar das observações do historiador, as idealizações não são ausentes no que se escreveu sobre o Brasil, como se vê na fantasia da natureza, da flora e da fauna e mesmo na criação de certas legendas.

Vê-se em muitos autores, portugueses ou não, ao tratar da história do povo português, a referência ao gosto pelo positivo, pragmático, empírico. Animava-os a açáo. $O$ rei $D$. Duarte, de curto reinado (1433-38), no seu livro $O$ leal conselheiro, referiu-se com desdém à " fan- 
tasia sem proveito". O país foi guiado, no período áureo e no que o preparou, por essa mentalidade, perdendo-a depois - a contar do século XVII, em esquematismo simplificador, quando começa também a sua decadência, pela incapacidade de organizar-se para explorar quanto obtivera com as viagens. Feita a parte mais difícil, seu aproveitamento coube a outros povos, que souberam capitalizar a aventura ibérica. $O$ tema é fascinante e já foi objeto de muito estudo denso, como se dá na obra do historiador e ensaísta Antônio Sérgio. Fica de lado, contudo. Lembrem-sc apenas duas passagens de Os lusiadas, em que Camões fala no "saber de experiências feito "(Canto IV, 94), ou, já no final do poema (Conto X, 153): "A disciplina militar, prestante / Não se aprende, Senhor, na fantasia, / Sonhando, imaginando ou estudando / Senão vendo, tratando c pelejando" (7). Podia dizer o mesmo que da disciplina militar de todos os outros saberes ou conhecimentos.

Na verdade, porém, o verificado era a ampliação do horizonte geográfico mais do que do horizonte histórico, pois as referências não importavam em incorporaçáo de outros povos: tomava-se conhecimento de um mundo mais amplo, explorava-se economicamente, na medida do possível, quanto se revelara. E era só. Essas terras pouco mais sugeriam. Seus habitantes, enquanto homens, não contavam: eram povos exóticos, com a atenção dada aos exotismos. O mundo americano não despertou imediatamente verdadeiro interesse. Os índios ou selvagens - como eram chamados - eram vistos como simples curiosidade, espécies estranhas que nāo seriam incorporadas à vida comum do tempo. Entre os que procuraram locais distantes, só administradores e padres tinham finalidade precisa: no mais, alguns aventureiros, cientistas ou simples curiosos vieram atraídos pelas riquezas ou pelo mistério. $O$ europeu do Renascimento não podia ter interesse por criaturas supostamente bárbaras ou lugares sem arte e sem conforto, embora Montaigne, em divagaçōes sobre os índios em seus Ensaios, escrevesse " não há nada de bárbaro e selvagem nessa nação (...) cada um chama barbárie o que não é de seu uso" (8). Demais, o Classicismo ou as lutas religiosas tomavam as atençôes e o curopeu tinha preocupaçōes até em excesso. E a América, por muito tempo, foi apenas a fornecedora de matéria-prima, campo de conquista de riquezas abundantes. Só a busca de riquezas justificava a sua procura.

E assim foi até o século XIX, quando passa a ser encarada como realidade, tal como devia ser, não apenas campo de aventuras e exploraçóes. $O$ ensaísta mexicano Edmundo $O$ 'Gorman estudou o assunto, " com a preocupação de saber como e de que maneira a Europa leva a cabo a incorporação da América, náo em termos políticos e institucio- 
nais, mas $\mathrm{cm}$ termos de convivência, fazendo-a partícipe de suas mais fundas preocupaçôes e admitindo-a como elemento constitutivo de sua situação histórica". De sua análise no livro Fundamentos da história da América, de 1942, destaca-se o ensaio "América na passagem do natural ao histórico", onde mostra como a Europa não tomou conhecimento do Novo Mundo do ângulo humano mais geral, como núcleo de homens iguais aos outros. Cita, como expressivo, o julgamento de Buffon, em sua História natural, excessivamente pessimista a respeito do continente: ele é mesmo aí apenas tema de história natural (9). Embora os enciclopedistas não ignorassem a realidade americana - lembre-se Raynal, vulgarizador do Iluminismo, sem originalidade ou solidez, em sua vasta obra em quatro volumes, da década de 70, Histoire philosophique et politique des établissements et du commerce des européens dans les deux Indes -, não a incorporaram ao processo histórico, significando que ela continua a não existir $\mathrm{em}$ certo sentido.

Entretanto, seria o caso de citar algumas exceçóes. Já no século XVI, em 1572, Jean Bodin, em Méthode pour faciliter la connaissance de $l$ histoire, colocou o problema em termos exatos: a América como objeto da história, em discreta censura aos historiadores por não a considerarem assim, de modo que ela cra mais referida pelos geógrafos. Bodin faz no seu texto curiosas e profundas observaçóes sobre a metodologia dos historiadores, censurando-os por náo tratarem, por exemplo, dos citas, hindus, etíopes e americanos (10). Não se alongue o assunto, mas deve-se destacar haver no texto importante subsídio para o entendimento de uma história universal, ainda distante nesse tempo e mesmo depois. Aliás, o problema é fascinante e não pode ser aqui abordado, resumindo-se agora ao realce da contribuição do versátil francês, homem dividido entre o tradicional e o moderno, cientista que se ocupa tanto de política e metodologia histórica como de demonologia - como é norma ainda no século XVI.

No século XIX há interessantes colocaçóes sobre a América entre vários expoentes do pensamento. Seria o caso de lembrar, por exemplo, Hegel, em suas Lifões sobre a filosofia da história universal. Reconhecendo ser "o Mediterrâneo o eixo da História Universal", exclui a Ásia remota e a Europa setentrional; "o que entendemos propriamente por África é algo isolado e sem História ". Mais: "a América deve afastar-se do solo em que, até hoje, se desenvolveu a história universal"; " a América não nos interessa" (11). Sem dúvida, uma estranha forma de pretender a história universal, excluindo quase tudo. Entre os seguidores do Evolucionismo, pensamento dominante então, é comum a atitude de menosprezo relativamente não só à América, mas a quase todo o mundo, pois 
se trata de modo de ver que mais privilegia a Europa, em perfeito exemplo de etnocentrismo, ou melhor, de provincianismo: o provincianismo europeu. Os principais autores do século pagaram tributo a esse sistema. A América permanecia de lado, embora já se escrevessem textos importantes sobre ela. Aproximação maior da idéia de universalidade da história, englobando todos os povos, na verdade só começa a firmar-se em nosso tempo. $\mathrm{O}$ assunto, porém, foge de todo ao objetivo desta comunicaçāo.

É preciso concluir. A América entra na história com a chamada Idade Moderna. O Novo Mundo começa na fase inaugural de novo tempo. Acontece, porćm, que a América portuguesa e espanhola - a chamada América Latina - foi em seu primeiro momento - o século XVI - saqueada cruelmente e vê suas várias civilizaçóes atingidas e até destruídas, como se deu, sobretudo, com as de mais desenvolvimento. Se o imperialismo na fase do capital mercantil e mesmo nas subseqüentes é sempre devastador, não tem respeito por nenhum povo, pois só se vê o interesse imediato, o lucro, tem-se aí a explicaçāo do processo selvagem de destruição direta ou indireta das culturas americanas, com a agravante do morticídio de milhóes, no mais significativo de todos os genocídios. Espoliada no período colonial, continuaria a ser mesmo após o surgimento das naçóes livres, a contar da segunda década do Oitocentos.

Não se recrimine tanto a nação de portugueses e espanhóis, pois outros, como ingleses, franceses, norte-americanos e mais conquistadores fizeram a mesma coisa na Ásia, na África e na América Latina com suas nações politicamente livres, mas dependentes pela subjugação econômica. O grave é a perseguiçáo do povo mais humilde - $\mathrm{O}$ índio pelos próprios governos, como é denunciado por todos os seus homens livres. Relembre-se o artigo de Mário Vargas Llosa aqui já citado, a outro propósito. Como diz até o título, "Emancipadas, ex-colônias não cooperam com índios". Assim nas antigas colônias da América espanhola ou portuguesa. $O$ continente foi sempre sacrificado e ainda o é. $O$ ideal de Bolívar de unidade não se verificou e a América independente com suas naçóes reproduz, em linhas gerais, não só a divisáo política feita pelo espanhol e pelo português como suas práticas brutais. Os esforços de mercados comuns ou coisas do gênero até hoje não deram resultado.

Como no presente o mundo é outro $\mathrm{e}$, graças sobretudo às ciências sociais, há um respeito por todas as culturas, consideradas legítimas, pois respostas aos desafios do meio e do tempo, pode-se esperar por melhores dias para a América, como para as outras áreas ainda em parte dominadas. O continente não se afirmou em sua plenitude, mas caminha para afirmar-se. A conjuntura internacional lhe é favorável. Neste final de 
século é legítimo ter esperanças. $O$ encontro de duas culturas deixará de ser um choque para ser uma complementaçâo, em processo harmonioso de convivência. Como se vê aqui, nesta reunião em que europeus e americanos se encontram para avaliar as suas trajetórias. Sem triunfalismos ou derrotismos, atitudes acríticas, mas em processo de conscientização de perspectivas e limites.

\section{Notas}

1 Jacob BURKHARDT - La culturn Ael Renacimiento en Italin - Barcelona, Iberia, Gil Editores, 1946, pp. 247-8.

2 Mario Vargas ILLOSA - Emancipadins, ex-colbrins nino cooperam com indios - "Folha de S. Paulo", Caderno especial de 12 de outubro de 1991.

3 Marc BLOCH - Apologic pour 1 7jistoire ou mbtier d historien - Paris, Librairie Armand Colin, 1952, p. 5.

4 ORTEGA Y GASSET - El tema de nusestro tiempo - Colección Austral, 11 - Cuarta edición - Buenos Aires/México, Espasa-Calpe Argentina, 1942, p. 18.

5 Claude IÉVI-STRAUSS - Entrevista a Antoine de Gaudemar, Libtrntion - transcrita em "Folha de S. Paulo" 5 de outubro de 1991.

6 Sérgio Buarque de HOLANDA - Visiño do paratso - Rio de Janeiro, Livraria José Olympio, 1959, pp. 3, 149, 343 e 166.

7 Luís de CAMŌES - Os lissindrus - Obras completas de... - Lisboa, Livraria Sá da Costa, vols. IV e V - Canto IV, 94 e Canto X, 153, pp. 238 e 261.

8 MONTAIGNE - Éssris, I - Paris, Garnier, p. 233.

9 Edmundo O'GORMAN - Fundamentos de la bistoria de Amtrica - México, Imprensa Universitaria, 1942, pp. 12 e 13.

10 Jean BODIN - Mttjode pour fruciliter la connaissance de l thistoire - Paris, Chez Martin Le Jeune, 1572 - In Ocumres plitosoplique de JB - Édition de Pierre Mesnard - Paris, Presses Universitaires de France, 1951, p. 286.

11 Hegel - Lecciones sobre In filosofin de la bistoria unipersal - Terceira edición - Madrid, Revista de Occidente, 1953 - I, pp. 183, 203 e 183.

\section{Resumo}

Discute-se a legitimidade da expressão descobrimento para o encontro de novas terras e populaçóes no expansionisıno dos séculos XIV e XV. O novo horizonte histórico resultante é marco na História, configurando o começo dos tempos modernos. Importa destacar o encontro de culturas diferentes, como se dá com a chegada do europeu à América. Do convivio dessas culturas resultou o processo de mútuas influências. Se o europeu impós mais os seus padróes, rambém absorveu traços culturais dos índios. O Novo Mundo é visto a 
princípio mais como Geogralia do que como História. Só a ciência social moderna compreende o problema, apontando-lhe soluçăo.

\begin{abstract}
The article discusses the legitimary of the use of the expression "discovery" for the finding of new land anda populations during the expansionism of the 14th and 15 th centuries. The resulting new historical horizon is a landmark in history, marking the heginning of modern times. It is imporrante to lows on the finding of different cultures, such as happened when Europeans arrived in America. The meeting of these cultures led to aprocen of mutual influencing, Although the Europeans imposed their culture to a greater extent, they also absorbed Idian cultural traits. Initially the New Word was seen more as a matter for Geography than History. Only modern social science is able to understand the problem and to point our a solution.
\end{abstract}

Francisco Iglesins é professor emérito da Universidade Federal de Minas Gerais (UFMG) e membro do Conselho do Instiruto Brasileiro de Política Cultural da Secretaria de Cultura e da Comissão de História da UNESCO. É autor de vários livros, entre os quais Política económica do governo provincial mineiro (1958), História e ideologia (1971), A revoluçăo industrial (1981), Caio Prado Júnior (1982), A industrializaçăo brasileira (1985) e Joaquim Nabuco (1991).

Comunicação apresentada dia 3 de abril de 1992 na sessão "Descubrimiento e Invención" do Simpósio El Descobrimiento de Occidente, promovido pela Fundación San Telmo, em Sevilla (Espanha). 